$0-23$

\title{
欠神発作モデルマウスにおける核内転写調節因子の挙動と $\mathrm{GABA}_{\mathrm{B}}$ 受容体拮抗薬の抗てんかん作用
}

\author{
伊藤 芳久, 石毛久美子, 愛澤 昌宏, 福田 英臣
}

\author{
日本大学薬学部薬理学教室
}

欠神発作は、行動の停止、凝視などの症状を呈する全般てんかんの一種である。ヒトにおいては、 発作に伴って脳波上に特徵的な両側同期性の䊂徐波複合放電 (spike and wave discharges, SWDs) が 認められる ${ }^{1)}$ 。欠神発作研究においては、 $\gamma$-ヒドロキシ酪酸 $(\mathrm{GHB})$ 、低用量のペンチレンテトラ ゾール、ペニシリンなどの薬物を投与して欠神様発作を誘発させる急性モデルが従来使用されてき た $^{2)}$ が、最近、欠神様発作を自発的に生じる粱歯類モデル $\left.{ }^{3,4}, 5\right)$ も開発されている。また、本発作 発現には、視床および大脳皮質が関与しており ${ }^{6)}$ ＧABAB アゴニストを視床に注入すると、久神 様発作と SWDs を生じること、また、この作用は GABAB アンタゴニストにより拮抗されることよ

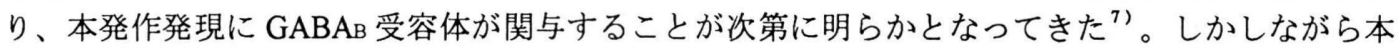
発作における $\mathrm{GABAB}$ 受容体の関与については不明な点も少なくない。また、カイニン酸 ${ }^{8)}$ やペン チレンテトラゾール ${ }^{9)}$ 誘発けいれんにより、脳内の転写調節因子が誘導されることが明らかとなっ ているが、欠神発作に関連する転写調節因子の誘導については不明な点が多い。そこで、本実験に おいては GHB のプロドラッグである $\gamma$ - ブチロラクトン $(\mathrm{GBL})^{2)}$ 投与マウスを急性モデルとして、 また、遺伝的モデルとして lethargic および stargazer マウスを用い、GABAB 受容体アンタゴニスト の欠神様発作に対する抗てんかん作用を調べるとともに、GBL 誘発欠神発作における核内 cyclic AMP responsive element (CRE) および activator protein 1 (AP-1) DNA 結合能の変化についても検討を 行った。

\section{実飡方法}

\section{1. 使用動物}

実験には 5-9 週齡の ddY 系雄性マウス、雌雄 lethargic (lh/hl) マウス、雌雄 stargazer $(\mathrm{stg} / \mathrm{stg})$ マウ スを用いた。Lethargic $(1 h / h)$ および stargazer $(s t g / s t g)$ マウスは、雌雄 B6C3H a/A-lh $(+h h)$ マウスお よび B6C3Fe a/a-stg (+/stg) マウスを Jackson Laboratory (Maine, USA)より輸入し、これらの動物か ら自家繁殖で得た。

2. 脳波測定

脳波記録用電極の装着は、Zornetzerの方法 ${ }^{10)}$ によった。ペントバルビタール麻酔下で、マウス の頭蓋骨を露出させ、bregma より後方 $2.0 \mathrm{~mm}$ 、左右 $1.5 \mathrm{~mm}$ の 2 カ所にドリルで穴をあけ、硬膜 上に電極の先端を接触させた。鼻骨にアースとしてステンレス製のネジを埋め込み、歯科用アクリ ルセメントで固定した。電極装着後 5 日以上の回復期間をおいた。

3. 核抽出液の調製とゲルシフトアッセイ

5週齢のddY系雄性マウスを用いた。核抽出液は、全脳または脳各部位より、Gorskiらの 方法 ${ }^{11)}$ で得た粗核画分から、Sakurai らの方法 ${ }^{21}$ で調製した。薬物はすべて腹腔内に投与した。 
ゲルシフトアッセイは、 ${ }^{32} \mathrm{P}$ で標識した 2 本銧 CRE または AP-1 DNA をプローブとして行った。 電気泳動後、ゲルを乾燥し、オートラジオグラフィー法でゲル中の放射能を検出した。用いた DNA プローブの配列は以下の通りである。(下線部はコンセンサスシークエンスを示す)

CRE : 5'-GATTGGCTGACGTCAGAGAGCT-3' AP-IDNA： 5'-GATCCGGCTGACTCATCACTAG-3'

\section{結 果}

薬物誘発および遺伝的動物モデルマウスにおける欠神様発作の特徴

GBL (70 - $100 \mathrm{mg} / \mathrm{kg})$ の投与 (GHB モデル) により欠神様発作（停止発作、凝視）が誘発され、 脳波上に 6-Hz の SWDs が出現した。また、lethargic および stargazer マウスでは、欠神様発作と発 作時に 6-Hz の SWDs が自発的に出現した (Fig. 1)。

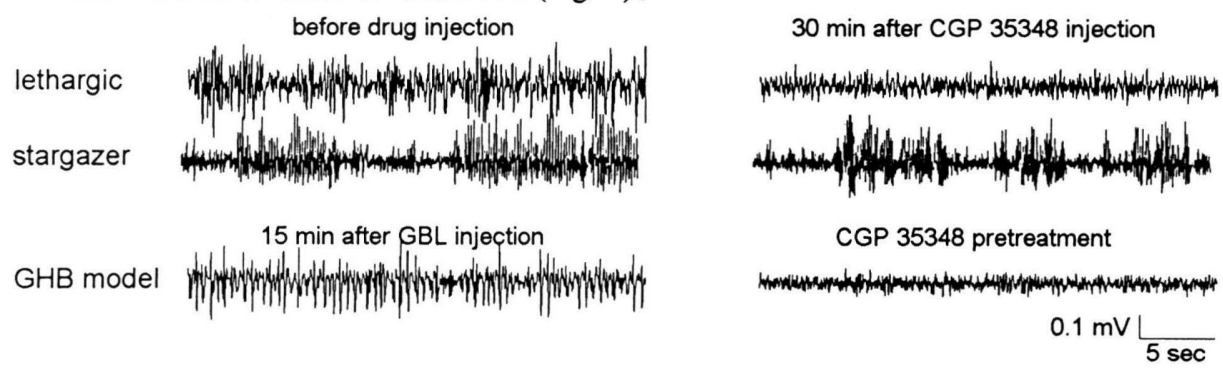

Figure 1. Effect of CGP 35348 on SWDs in lethargic, stargazer and GHB model mice. Electrocorticogram (ECoG) patterns before and after CGP $35348(200 \mathrm{mg} / \mathrm{kg})$ administration are shown. In the GHB model, a dose of GBL $(70 \mathrm{mg} / \mathrm{kg}$ ) was given. Representative bipolar ECoGs from left and right hemispheres are shown. All drugs were injected intraperitonially.

\section{各種モデルマウス SWDs に対する各種薬物の影響}

Lethargic, stargazer マウスの自発的 SWDs および GBL 誘発 SWDs に対する各種薬物の影響を検討 した。代表的な欠神発作治療薬であるエトスクシミド $(200 \mathrm{mg} / \mathrm{kg})$ は、用いたすべてのモデルに おいて SWDs の発現を抑制した。GABAB 受容体アンタゴニストのCGP 35348 (200 m $\mathrm{mg} / \mathrm{kg})$ また は CGP $46381(60 \mathrm{mg} / \mathrm{kg})$ の投与により、GBL 誘発および lethargic マウスの SWDs 発現は抑制され たが、stargazerマウスのそれは CGP 35348 (200 mg/kg)により影響を受けなかった (Fig. 1)。

\section{GBL 誘発欠神様発作における転写調節因子の誘導}

GBL $(100 \mathrm{mg} / \mathrm{kg})$ 投与後、全脳より核抽汁液を調製し、CREおよびAP-1 DNA 結合能を調べた。 $\mathrm{CRE}$ 結合能は、投与 5 分後に上昇傾向を示し、30 分後に增加は最大となったが、90 分後には投 与前のレベルに回復した。AP-1 DNA 結合能は、投与. 5 分後にすでに有意な上昇が認められ、15 分後から 60 分後までプラトーとなったが 90 分後においても高いレベルを保持していた。また、こ れらのDNA結合能上昇の用量依存性を㭘射したところ、欠神様発作が認められない $25 \mathrm{mg} / \mathrm{kg}$ で は、両 DNA 結合能ともに変化は認められなかったが、発作が認められる $50 \mathrm{mg} / \mathrm{kg}$ から $400 \mathrm{mg} / \mathrm{kg}$ の範囲で濃度依存的に増加した (Fig. 2)。

GBL 投与による核内 CRE および AP-1 DNA 結合能の上昇は、欠神様発作および SWDs の場合と 同様にCGP $35348 \quad(200 \mathrm{mg} / \mathrm{kg})$ の前処置で拮抗された。全脳で認められた CREおよび AP-1 DNA 結合能の上昇をさらに詳しく検討するため、GBL 投与後に脳を各部位に分画し、それぞれの 部位から得られた核抽出液を用いてゲルシフトアッセイを行ったところ、CRE およびAP-1 DNA 結合能ともに大脳皮質および視床一中脳で有意な增加が認められた (Fig. 3)。しかし、海馬および 
図には示していないが、視床下部、小脳、橋一延剈道では両結合能ともに有意な変化は認められなか った。また、大脳皮質および視床一中脳で認められた CRE およびAP-1 DNA 結合能の上昇も、全 脳の場合と同様にCGP 35348 の前処置で拮抗された。
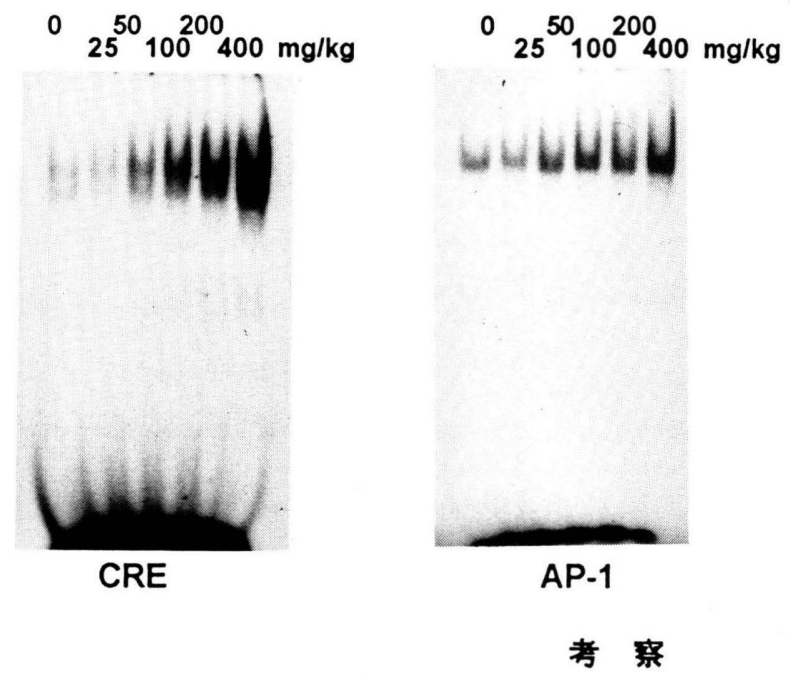

Figure. 2. Dose-dependent induction of nuclear CRE- and AP-1 DNA-binding activities by GBL in mouse whole brain. Nuclear extracts were prepared 30 min after GBL administration.

欠神発作の発現には、視床および大脳皮質、特に視床 - 大脳皮質回路 (tharamocortical circuitry) が重要な役割を演じており、けいれんを伴う発作の場合とは異なり海馬の関与はないことが報告さ れている ${ }^{1,2)}$ 。視床ニューロンは大脳皮質に投射しているが、このニューロンは視床網様核由来の

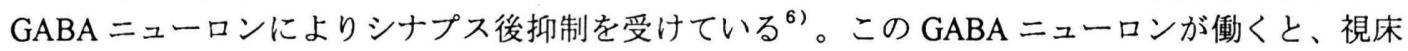
ニューロンにおいて GABAA 受容体を介した速い抑制性シナプス後電位 (IPSP) と GABAB 受容体を 介した比較的ゆっくりした IPSP が観察されるが、この GABAB 受容体依存性の IPSPにより、 低閾值 $\mathrm{Ca}^{2+}$ チャネルが脱抑制をうけて開口 Loscillatory burst firing 生じる。この oscillatory burst firing が大脳皮質ニューロンに伝えられる。これら一連の現象により、脳波上に SWDs が生

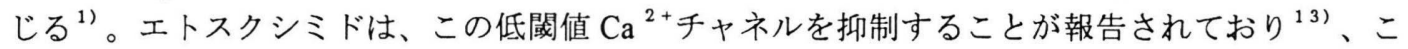
の作用が抗けいれん作用と関連していると考えられている。

本研究において、GBL または GHB 投与により、Snead ら ${ }^{2)}$ のラットやサルでの報告と同様に マウスにおいても欠神様発作および 6-HZ の SWDs が認められた。また、lethargic および stargazer マウスでは自発的な欠神様発作と 6-HZ の SWDs が認められた。これらのマウスにおける欠神様発 作および SWDs は、代表的欠神発作治療薬であるエトスクシミドにより抑制されたことから、い ずれのモデルにおいても、低閾值 $\mathrm{Ca}^{2+}$ チャネルの脱抑制による視床ニューロンの oscillatory burst firing が発作発現に関与していることが考えられる。また、GABAB アンタゴニストの CGP 35348 およびCGP 46381 は、GBL 誘発およびlcthargic マウスの欠神様発作と SWDsに対し顥著な抑制作 用を示した。これらの結果は、genetic absence epilepsy rats from Strasbourg (GAERS)における自発 的欠神様発作が CGP 35348 で抑制されるとの報告 ${ }^{3)}$ と一致しており、GHB モデル, lethargic マウ スおよび GAERSにおいては、GABAB 受容体が欠神発作発現に重要な役割を演じていることが示 唆される。また、これらの欠神発作モデルにおいて GABAB アンタゴニストが強力な抗てんかん作 用を示すことが確認された。しかし、stargazer マウスの欠神様発作および SWDs は、GHB モデ ルやlethargicマウスで抗けいれん作用を示す用量のCGP 35348で抑制されなかったことから、 stargazer マウスの欠神様発作発現には GHB モデル, lethargic マウスおよび GAERS とは異なる機 構が関与していることが考えられる。 


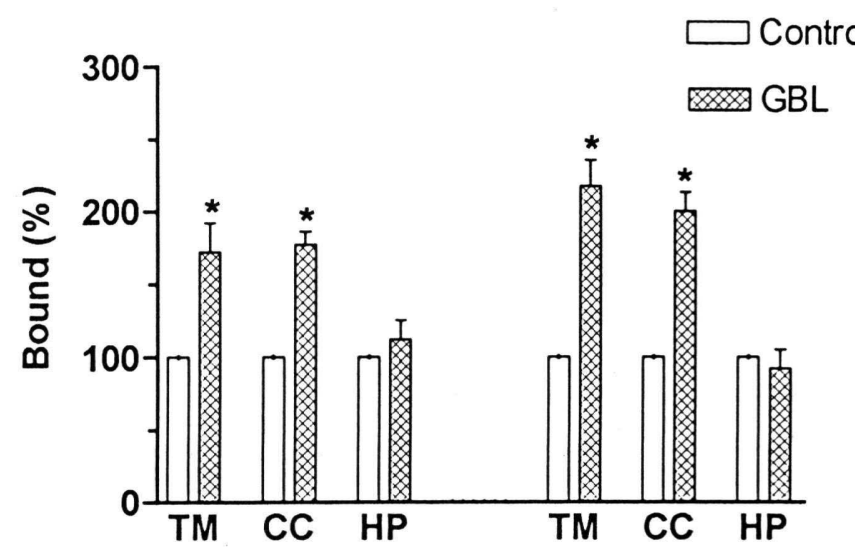

Figure 3. Region specific increases in nuclear CRE- and AP-1 DNA-binding activities after GBL administration in mouse brain. Nuclear extracts were prepared $30 \mathrm{~min}$ after GBL administration. Each value represents the mean \pm SEM of three independent expreiments.

* $\mathrm{P}<0.05$ as compared with control value. TM: thalamus + midbrain, CC: cerebral cortex, HP: hippocampus

本研究から、欠神様発作および SWDs が認められる用量の GBL の投与により、全脳における CRE およびAP-1 DNA 結合能の有意な増加が認められること、さらに、これらの DNA 結合能の上 昇は部位特異的な変化で、視床一中脳および大脳皮質では認められるが、他の部位では認められな いことが明らかとなった。これらの結果は、核内の転写のレベルで見た場合にも GBL 誘発欠神発 作に、視床および大脳皮質が重要な役割を演じていることを示唆している。カイニン酸 ${ }^{8)}$ やペンチ レンテトラゾール ${ }^{9)}$ 投与などによるけいれんにおいては、AP-1 DNA 結合能の上昇や、c-Fos 誘導 が海馬や大脳皮質で起こること報告されているが、部位的に見た場合本実験における GBL 誘発欠 神様発作に伴う AP-1 DNA 結合能の増加は、薬物誘発けいれんの場合とかなり異なっている。さ らに、GBL 投与による CRE およびAP-1 DNA 結合能の上昇は、久神様発作および SWDs の場合 と同様に GABAB アンタゴニストにより抑制されたことから、これらの DNA 結合能が視床-大脳皮 質ニューロンの oscillatory burst firing と密接に関連していることが考えられる。

以上より、GABAB アンタゴニストが、欠神発作モデル動物において顕著な抗てんかん作用を示 すこと、また、GBL 誘発欠神様発作では、発作発現に伴い視床一中脳および大脳皮質において核内 CRE 及びAP-1 DNA 結合活性が上昇するが、この上昇も GABAB アンタゴニストにより拮抗され ることが示された。

\section{謝 辞}

CGP 35348 および CGP 46381 をご提供くださった CIBA-GEIGY 社に深謝いたします。

\section{文 献}

1) Snead III OC: Basic mechanisms of gencralized absence seizures. Ann Neurol 37, 146-157 (1995)

2) Snead III OC: Pharmacological models of gencralized absence seizures in rodents. J Neural Transm 35, Supp, 7-9 (1992)

3) Liu $Z$, Vergnes $M$, Depaulis $A$ and Marescaux $C$ : Involvement of intrathalamic GABAB neurotransmission in the control of absence seizures in the rat. Neuroscience 48, 87-93 (1992)

4) Hosford DA, Clark S, Cao Z, Wilson WA, Lin F-H, Morrisett RA and Huin A: The role of GABAB receptor activation in the absence seizures of lethargic (Ih/h) mice. Science 257, 398-401 (1992)

5) Noebels JL, Qiao X, Bronson RT, Spencer C and Davisson MT: Stargazer: A new neurological muatant on chromosome 15 in the mouse with prolonged cortical seizures. Epilepsy Res 7, 129-135 (1990) 
6) Striade $M$ and Llinas $R R$ : The functional states of the thalamus and the associated neuronal interplay. Physiol Rev 68, 649-742 (1988)

7) Liu Z, Vergnes M, Depaulis A and Marescaux C: Evidence for a critical role of GABAergic transmission within the thalamus in the genesis and control of absence seizures in the rat. Brain Res 545, 1-7 (1991)

8) Pennypacker KR, Walczak D, Thai L, Fannin R, Masan E, Douglass J and Hong JS: Kainateinduced changes in opioid peptide genes and AP-1 protein expression in the rat hippocampus. J Neurochem 60, 204-211 (1993)

9) Sonnenberg JL, Mitchelmore C, Macgregor-Leon PF, Hempstead J, Morgan JI and Curran T: Glutamate receptor agonists increase the expression of Fos, Fra, and AP-1 DNA binding activity in the mammalian brain. J Neurosci Res 24, $72-80$ (1989)

10) Zornetzer S: A simple and reliable chronic brain implantation technique for the mouse. Physiol Behav 5, 1197-1199 (1970)

11) Gorski K, Carnerio $M$ and Schibler U: Tissue-specific in vitro transmission from the mouse albumin promoter. Cell 47, 767-776.

12) Sakurai H, Kurusu R, Sano K, Tsuchiya $T$ and Tsuda M: Stimulation of cultured cerebellar granule cells via glutamate receptors induced TRE- and CRE-binding activities mediated by common DNA-binding complexes. J Neurochem 59, 2067-2075 (1992)

13) Coulter DA, Huguenard JR and Prince DA: Characterization of ethosuximide reduction of lowthreshold calcium current in thalamic neurones. Ann Neurobiol 25, 582-593 (1998)

Abstract - Induction of transcription factors and antiepileptic effect of GABAB anatagonists in absence seizure model mice. Yoshihisa ITO, Kumiko ISHIGE, Masahiro AIZAWA and Hideomi FUKUDA (Depatment of Pharmacology, College of Pharmacy, Nihon University, 7-7-1 Narashinodai, Funabashi-shi, Chiba 274, Japan). Folia Pharmacol. Jpn. 106 (suppl.1), 172 P 176 P (1995)

Pharmacological profiles of gencralized absence-like seizures in animal models were studicd. Selective GABAB antagonists, CGP 35348 and CGP 46381, suppressed absence seizure behavior and spike and wave discharges (SWDs) in lethargic ( $/ h / h h)$ and $\gamma$-butyrolactone (GBL)-treated mice but not in stargazer (stg/stg) mice. Administration of GBL increased nuclear CRE- and AP-1 DNA-binding activities in mouse whole brain. CGP 35348 suppressed the increases in DNA-binding activities. It has been shown that the cortical and thalamic circuitry plays an important role in the genesis and spreading of absence seizures.

Gel-shift assays in various brain regions revealed that administration of GBL increased nuclear CRE- and AP-1 DNA-binding activities significantly in the thalamus + midbrain and cerebral cortex but not in the hippocampus, cerebellum or pons-medulla. The region-specific increases in nuclear DNA-binding activities were also suppressed by CGP 35348. These results suggest that GABAB receptors play a significant role in generalized absence seizures in lethargic and GBL-treated mice and that the increases in nuclear CRE- and AP-1 DNA-binding activities are correlated with the GBL-induced absence seizures. It is also suggested that different mechanisms are involved in absence seizures in stargazer mice. 